\title{
A historiografia isidoriana: teologia e política
}

\author{
Isidorian historiography : theology and politic
}

\section{Sergio Alberto Feldman ${ }^{1}$}

\section{RESUMO}

Isidoro de Sevilha é um bispo visigodo da Antiguidade Tardia, autor de vasta obra exegética, teológica e também historiográfica. Este artigo visa a entender a função e o objetivo da obra historiográfica isidoriana, no contexto da evangelização da Península Ibérica e da busca de legitimação e fortalecimento da Monarquia católica, como aliada da Igreja. A escrita da história em Isidoro tem motivações diversas, sendo moldada a partir de interpretações teológicas e pretendendo gerar modelos comportamentais aos reis, aos nobres e clérigos, e aos demais setores sociais. O sentido pedagógico se sobressai, junto com a visão teleológica.

Palavras-chave: Isidoro de Sevilha; Historiografia; Modelo monárquico.

\section{ABSTRACT}

Isidore of Seville is a Visigothic Bishop of Late Antiquity, author of an exegetical, and theological work, as well as historiography. This article aims to understand the function and purpose of the isidorian historiographic works in the context of the evangelization of the Iberian Peninsula and the quest for legitimization and the strengthening of the Catholic monarchy, having the Church as an ally. The writing of history in Isidore has different motivations, being molded from theological interpretations and intent on generating behavioral models to kings, nobles and clergy, and other social sectors. The pedagogical sense stands, along with the teleological view.

Keyword: Isidore of Seville; Historiography; Monarchical model.

1 Doutor em História pela UFPR. Membro do Programa de Pós Graduação em História Social das Relações Políticas da UFES, Vitória, Espírito Santo. Este é um trabalho preliminar no âmbito de um estágio Pós Doutoral realizado em Paris (França) junto ao EHESS patrocinado pela CAPES. 
O bispo Isidoro de Sevilha viveu na Hispânia Visigótica, entre 576 e 636 da Era Comum, e foi um catalisador de diversos projetos religiosos e culturais no reino visigótico de Toledo, sendo consultor de alguns reis e coordenador do quarto Concílio de Toledo (633) que definiu as políticas religiosas e objetivou obter algum tipo de estabilidade política à instável Monarquia. Por cerca de um quarto de século, foi a figura mais importante no reino e deixou vasta obra literária, entre as quais algumas de caráter historiográfico. $\mathrm{O}$ presente estudo busca explorar "a visão isidoriana da política e da sociedade" e a função "pedagógica" de suas obras históricas. A obra isidoriana busca adequar a política á religião, inserindo a teologia e a moral, na construção de um sentido para a política e instrumentalizando a monarquia como um meio para uma finalidade cristã de sociedade e de uma teleologia. Isidoro não é o pioneiro, neste projeto. Há uma continuidade entre ele e os pensadores cristãos da assim denominada Patrística, especialmente a ocidental.

Ao estudá-lo, consideramos adequado fazer uma breve e sucinta análise dos cronistas ${ }^{2}$ que antecederam sua obra, para depois analisar seu contexto e produção historiográfica. Assim sendo, delimitaremos duas partes de nossa análise. Passemos à primeira delas que se aloca entre o século IV e o final do século VI.

\section{A historiografia clerical tardo antiga: antecessores de Isidoro de Sevilha ${ }^{3}$}

A historiografia cristã tem como marco definidor as obras do bispo Eusébio de Cesaréia, que viveu no momento da aproximação da Igreja com o Império, sob Constantino, o Grande. $O$ início do século IV é o momento de uma guinada radical nas relações entre o governo imperial e os cristãos. Esse processo suscitou uma nova leitura historiográfica que interpretou a realidade e concebeu uma filosofia da História providencialista que explicava tanto os conflitos e perseguições aos cristãos no século III e anteriores, como a recente aproximação.

Deus, como o protagonista de um projeto de História, estava inserido nessas mudanças e o Império era o espaço escolhido pela Divina providência para que, nessa unidade política, ocorresse uma unidade religiosa que levasse ao Reino de Deus, na Terra, e à segunda vinda de Jesus Cristo, ou seja, a Parúsia. Nas palavras de François Hartog, suas obras historiográficas, incluídas a biografia e o elogio a Constantino, proclamam "[...] a verdade do Cristianismo e a missão providencial do imperador romano" (HARTOG, 2001, p. 257).

\footnotetext{
${ }^{2}$ Optamos por não diferenciar historiadores e cronistas, pois essa condição é imprecisa. Nesse período, a maioria dos autores são clérigos e identificados com a Cristandade.

${ }^{3}$ Fazemos uso do conceito de Antiguidade Tardia que define um período alocado entre o mundo antigo e o medievo. As permanências e continuidades são ênfase dessa percepção historiográfica. Historiadores como H. I. Marrou e Peter Brown são referências fundamentais dessa concepção. Alguns autores se opõem a essa historiografia. Não nos alongaremos na definição da mesma.
} 
A historiografia eusebiana deve seu ponto de partida ao modelo de crônica universal instituído por Sexto Júlio Africano no terceiro século e que serviu a Eusébio de Cesaréia e aos seus diversos sucessores e continuadores, como Jerônimo, Próspero de Aquitânia, Victor de Tunnuna, Paulo Orósio, João de Biclaro e Isidoro de Sevilha. O propósito principal do gênero das crônicas universais, em suas diversas versões e continuações, era apologético. A polêmica que já ocorrera nos dois séculos anteriores, contrapondo os cristãos com os pensadores pagãos nas cidades helenísticas, trazia, em sua pauta, a questão da tradição e da antiguidade da "nova religião", que não teria status de religião lícita e tradicional. Urgia provar que a história dos hebreus, leia-se cristãos, que seriam o verdadeiro Israel, era tão ou ainda mais antiga que as histórias da Grécia e de Roma. Era fundamental, portanto, provar que de Abraão a Constantino havia uma continuidade, uma tradição milenar que gerava uma legitimidade à "nova” religião.

A raison d'être da historiografia cristã seria apologética e comprobatória de uma antiga e sedimentada tradição que gerava uma espécie de nobre continuidade. Isso conflitava com os judeus que não estavam dispostos a dividir seus personagens tradicionais e perder a sua condição de herdeiros da condição de "povo eleito", membros de um pacto com Deus e continuadores de uma estirpe de patriarcas, profetas e da dinastia davídica, da qual o Ungido (Messias) deveria sair, na concepção judaica, ou já viera em Jesus, na percepção cristã.

Eusébio de Cesaréia, em sua história eclesiástica, define o novo gênero como uma história que tem um sentido de exemplo, no modelo da Res Gestae clássica, mas agrega o conceito de preservar e transmitir aos sucessores dos apóstolos, ou seja, os bispos e demais clérigos a eles subordinados, a tradição apostólica que seria "[...] a garantia de autenticidade da doutrina" (HARTOG, 2001, p. 267). Entra em cena a história vinculada à instituição, à autoridade e à memória religiosa. Hillgarth (1985, p. 263) concorda que a tradição da História cristã, que percebe a ação da Providencia através dos tempos, remonta a Eusébio de Cesaréia.

Eusébio parte do pressuposto de que Roma é o instrumento de Deus, substituindo o povo de Israel, e esta percepção se manterá com sutis alterações até a escrita historiográfica de Isidoro de Sevilha. Diz Hillgarth (1985, p. 263): "[...] A interpretação de Eusébio sobre a história de Roma como o instrumento escolhido por Deus no lugar de Israel, é encontrada em escritores espanhóis do início do século quinto, em Orosius e em Prudêncio [...]". ${ }^{4}$ Há uma linha de continuidade de Eusébio até Isidoro, mas há certas mudanças e adaptações, que as novas realidades e conjunturas exigiriam.

O termo eusebiano para cristãos é éthnoi neoi, ou nova nação, que ele usa na História Eclesiástica e está vinculado a uma linha de sucessões que começa em Jesus, segue nos apóstolos e prossegue no episcopado (HARTOG, 2001, p. 267). Eusébio organiza a cronologia

${ }^{4}$ [...] Eusebius' interpretation of the history of Rome as the chosen instrument of God in place of Israel, is found in early fifth-century Spanish writers, in Orosius and in Prudentius [...]. 
em torno das informações emanadas da Bíblia, começando na Criação e culminando no Juízo Final (TÉTART, 2000, p. 35). A história adquire uma "[...] lógica contínua, espécie de itinerário iniciático. Autêntica filosofia da história, a representação do povo cristão em marcha para a beatitude [...]" (TÉTART, 2000, p. 35).

A função da História seria manter a mensagem inicial correta e adequada, vinculada à autoridade apostólica, à tradição e à continuidade da Revelação. Não é mais o autor e suas fontes, no modelo de Tucídides ou Políbio, que analisa versões antagônicas, e nem são os depoimentos de testemunhas que definem o fato. Agora há a inserção da tradição e da Revelação. A citação, a "autoridade", fundamental nas obras medievais, e não os fatos e fontes são o argumento (QUEIROZ; IOKOI, 2003, p. 45). A inspiração divina é um instrumental necessário ao historiador. Eusébio roga a Deus "[...] que seja seu 'guia' no trabalho" (HARTOG, 2001, p. 267), pois é o pioneiro nessa nova escrita da História. Seu modelo será repetido por quase todos, senão todos os cronistas clericais que o sucederam.

A obra de Eusébio teve continuadores de estilo refinado, que prosseguiram escrevendo uma história cristã. Jerônimo traduziu a História eusebiana do grego para o latim, adaptando-a e continuando-a (QUEIROZ; IOKOI, 2003, p. 44-45). Ao traduzir, insere temas e focos da parte ocidental do Império, que o antecessor negligenciara em prol de temas do Oriente, onde vivera toda a sua vida. Além dessa diferença, há oposição em alguns focos de finalidades da obra: para Eusébio, o foco no reinado de Constantino é central e nele ocorre a confluência da história greco-romana com a judaico-cristã, criando um eixo delineador dessa nova historiografia; já para Jerônimo que escreve cerca de meio século depois, o evento que demarca a sua versão aparece no final desta: a derrota do exército imperial diante dos visigodos em Adrianopla (378) com a morte de Valente e a permanência dos visigodos no Império, a partir desse fracasso romano. Os motivos de Jerônimo não são esclarecidos: pode ser que ele tivesse certa preocupação e motivações apocalípticas, mas mesmo não se podendo afirmar essa proposição como segura, ela demarca a presença de novos protagonistas no palco da História: os povos bárbaros.

Os cronistas que escrevem a partir de Jerônimo, têm que dialogar entre a expansão do Cristianismo, as dificuldades do Império, especialmente em sua parte ocidental, e agora também com os povos bárbaros que conturbam e gradualmente solapam a estabilidade do poder imperial. Há transição de uma visão do Império cristão, universal e unificado, que vigorava na versão eusebiana, para as relações de um ainda ambicionado Império com os invasores.

Um dos sucessores desses autores foi Próspero de Aquitânia, que fez um sumário abreviado de seus antecessores e seguiu na escrita da crônica de seus tempos. Ele era secretário do bispo de Roma, o Papa Leão I, em 455. Manteve um foco romanocêntrico ocidental, definindo a cronologia pelos cônsules de Roma. $\mathrm{O}$ combate às heresias e a defesa da ortodoxia estão na pauta central da obra. 
Próspero relata as invasões de lombardos, burgúndios, hunos, godos e vândalos. Estes últimos têm um foco diferenciado e bastante crítico na obra, pois o saque de Roma pelos vândalos ocorre em 455 e, nessa data, Próspero vivia em Roma. Além disso, a postura do rei Genserico a favor do Cristianismo, na versão ariana, é motivo de amplas e detalhadas observações do autor. Próspero é claramente antiariano, antivândalo, e tem muita influência no fato de o substantivo vândalo ter se tornado um adjetivo (WOLF, 1999, p. 4). A postura dele, em relação a outros povos invasores, não é tão aguda, e mesmo os visigodos, que só virão a se tornar católicos em 589 , e saquearam Roma já em 410 , não recebem um tratamento tão ríspido. Na opinião de Wolf (1999, p. 4): "Prospero se centrou tanto no barbarismo dos vândalos que suas referencias às incursões de outros povos, especificamente dos Godos, se mostram superficiais por comparação".

Não há tanta ênfase na violência e tampouco na atitude "não civilizada" dos visigodos. É fato que para autores como Jerônimo o saque de Roma em 410, pelos visigodos, foi visto como um acontecimento catastrófico; para Agostinho, foi o elo motivador da escrita da obra "Cidade de Deus". Ainda assim, Próspero economiza nas críticas aos visigodos e enfatiza seu papel na contenção dos hunos, como aliados do Império.

A importância de Agostinho de Hipona nas obras dos cronistas cristãos deste período é notável. Optamos, pelas limitações deste trabalho, por lembrar a forte influencia dele na obra isidoriana. $^{6}$

Para não nos alongarmos muito, enfocaremos apenas outros dois historiadores. $\mathrm{O}$ primeiro deles é Paulo Orósio, um clérigo hispânico que em 414 foge das invasões germânicas na península ibérica e se refugia em Hipona. Discípulo de Agostinho, o bispo local, e defensor da ortodoxia, no viés agostiniano, escreve uma obra historiográfica que amplia e dialoga com a concepção de mundo emanada na obra 'Cidade de Deus'. Orósio escreve a 'História contra os pagãos' (415-417) objetivando provar, entre outras coisas, que o cristianismo não fora responsável pela tomada de Roma pelos visigodos, e também para a crise que se sucedeu, concebendo que a análise da história humana demonstra um desígnio providencial. Orósio é fonte fundamental a todos os escritores cristãos medievais e mesmo posteriores (QUEIROZ; IOKOI, 2003, p. 46). Orósio tenta provar que toda a história humana antes da vinda de Cristo não é senão a consequência ou o castigo consecutivo ao pecado

\footnotetext{
${ }^{5}$ Prosper focused so much on the barbarism of the Vandals that his references to the incursions of other peoples, specifically the Goths, seem perfunctory by comparison.

${ }^{6}$ Sugestões de leitura no tema da influência de Agostinho na historiografia cristã: BROWN, P. Santo Agostinho: uma biografia. Trad. de Vera Ribeiro. Rio de Janeiro: Record, 2008, p. 373-411; CHADWICK, H. Augustine of Hippo: a life. Oxford: Oxford University Press, 1986, p. 123-144; e o clássico MARKUS, R. A. Saeculum: History and Society in the Theology of Augustine. Cambridge: Cambridge University Press, 1970 [reimpressão 2007]. Optamos por citar novamente estas obras nas referencias, mesmo se tratando apenas de sugestões de leitura e não terem sido utilizadas na escrita deste texto.
} 
original (TÉTARD, 2000, p. 37). O sentido providencialista da história cristã se molda plenamente.

Abre-se o caminho para uma reviravolta no modelo eusebiano: precisa-se achar um substituto para o Império que sobrevive no Oriente, mas minguara no Ocidente. Urge achar um substituto ocidental para o modelo constantiniano. E outro "povo eleito", no âmbito dos povos invasores. Afirma Hillgarth (1985, p. 264-265), que: “[...] então você pode identificar a tribo dominante local, francos ou visigodos, como instrumento de Deus, e atribuir a seu governante a aura de Constantino, um pouco esmaecida, talvez, mas ainda visível". ${ }^{7}$ Assim veremos na obra de Isidoro de Sevilha, em relação a monarquia visigoda, e de maneira similar poder-se-ia ver na obra de Gregório de Tours, em relação a monarquia franca merovíngia (SILVA, 2008). Associar um novo poder cristão aos projetos clericais de encaminhar o mundo, na sua correta direção: evangelizar os pagãos, redimir os hereges e os renitentes judeus e expandir a fé. $O$ poder político seria um instrumento de tal projeto.

Entre os predecessores de Isidoro de Sevilha, o mais influente e próximo foi o abade João de Biclaro, ou o Biclarense. É o historiador da transição entre o modelo imperial e um novo, que enfoca nos reinos bárbaros. Este autor faz uso dos imperadores orientais como base cronológica e mostra a sua experiência e estágio em Constantinopla onde, de acordo com Isidoro de Sevilha, na sua obra De viris illustribus, o Biclarense viveu de c. 559 até c. 576, estudando por cerca de dezessete anos (ISIDORO DE SEVILHA, 1855 (1), PL, 44). ${ }^{8}$ O Biclarense é autor de uma obra romanocêntrica que é fundamental para a escrita da História isidoriana. As informações do final do século VI, que constam da História Isidoriana, têm o abade de Biclaro como fonte principal. ${ }^{9}$

Uma das maneiras de entender uma época e analisar seus valores é buscar as fontes históricas redigidas por algum (alguns) historiador(es) contemporâneo(s) à mesma época. Essa perspectiva pode ser uma autoimagem, distorcida ou idealizada, dependendo da posição do autor na sociedade e na política de então. Quando o autor é uma das personalidades mais marcantes de sua geração, aumenta a importância de sua visão, pois reflete nas entrelinhas a concepção do "projeto de sociedade" que ele almeja. Seria esse o caso de Isidoro: o Hispalense ${ }^{10}$ não tinha, na escrita da história, uma ocupação constante, mas foi autor de obras históricas que trazem inúmeras informações e propiciam espaço para reflexões sobre a sua visão da História e de sua finalidade, além de uma visão da política e da

\footnotetext{
7 "[...] then you could identify the local dominant tribe, Franks or Visigoths, as God's instrument, and attribute to its ruler the aura of Constantine, a little dimmed perhaps but still visible".

${ }^{8}$ A citação de obras da coletânea PATROLOGIA LATINA=PL dispensa a data. Uma imensa coletânea de toda a Patrística latina editada por MIGNE em meados do século XIX, entre c. 1844 e 1855 e reeditada em fac-símile na década de 1950. A menção da obra e do volume é aceita em edições de artigos de história antiga e medieval. Por exigência da editoria da revista colocamos uma data para manter o padrão ABNT. Usaremos a data de 1855.

${ }^{9}$ João de Bíclaro é uma fonte importante para Isidoro. Autor da "Crônica", composta quando ainda era abade (depois foi bispo de Gerona e veio a morrer em 621), viveu parte de sua vida em Constantinopla e conhecia muito bem a corte imperial. Escreveu sobre os anos 567 e 591, descrevendo o reinado de Leovigildo e parte do reinado de Recaredo. Como o período é o da unificação religiosa, torna-se fonte fundamental.

${ }^{10}$ Hispalis seria o nome, em latim, de Sevilha. O Hispalense seria Isidoro, bispo de Sevilha.
} 
religião, com as implicações sociais a elas inerentes. Propomo-nos a analisar algumas de suas obras históricas, na busca destes elementos: a sua visão da História e do final dos tempos, da sociedade e do modelo de governo cristão que almejava para a sociedade na qual vivia.

\section{As obras históricas de Isidoro de Sevilha}

Entre as obras históricas de Isidoro, podemos citar: a "Crônica", a "Historia" ${ }^{11}$, e sua versão do "De viris".

A primeira é uma obra sintética que, de maneira simples, narra a história do mundo desde a Criação até o reinado de Sisebuto, provavelmente época em que foi escrita. $\mathrm{Na}$ última parte, a obra se concentra em temas relacionados com a Hispania. Aplica a teoria das seis idades do mundo, que Isidoro delineia de maneira clara e sintética nas "Etimologias" (ISIDORO, 1951, p. 21) e que tem forte influência do pensamento de Agostinho de Hipona e sua filosofia da História. ${ }^{12}$ A sexta era está marcada pela presença do Império Romano: toda a cronologia oferece uma inter-relação entre Roma e a Cristandade a partir dessa era; os trechos estão demarcados pelos reinados de imperadores, dentro dos quais se citam algumas notícias e assuntos importantes, geralmente fatos políticos e religiosos ocorridos tanto no Ocidente quanto no Oriente (CAZIER, 1994, p. 14-15; ISIDORO, 1855 (2), PL, t. 83, c. 1038-1058, v. 66-122). ${ }^{13}$ Essa conjugação de fatos da Igreja com os de imperadores e seus reinados deixa clara a herança da crônica de Eusébio e dos vínculos com o Império. Isso mudará na "História", sua obra posterior. Qual a razão de ser de tal aderência?

Isso se deve à ausência de outras cronologias e à necessidade de apoiar-se em diversas obras, todas elas escritas sob o signo do Império e de reinados. Mas Isidoro não deixa de salientar a sua visão da ascensão e queda dos impérios: o Império Romano se revelava como o último dos grandes impérios e seria substituído pelo reino de Deus, com o retorno ou segunda vinda de Jesus Cristo (ISIDORO, 1855 (2), PL, t. 83, c. 1056, v. 122). As breves citações de fatos ocorridos no reino visigótico são escolhidas cuidadosamente: uma ênfase especial é dada tanto à conversão de Recaredo quanto a dos judeus sob Sisebuto, mostrando a sua importância no contexto da história universal.

Há muitos indícios de que a obra tem alguma relação com um forte sentimento escatológico que previa um próximo fim de mundo (ISIDORO, 1855 (2), PL, t. 83, c. 1056, v. 122;

\footnotetext{
${ }^{11}$ O nome das obras são 1) "Chronica ou Chronicon". 2) "De origine Gothorum. Historia Wandalorum. Historia Suevorum ou Historia de regibus Gothorum, Wandalorum et Sueborum". 3) A "De viris", citaremos como ISIDORO, 1855 (1), PL. A segunda referenciaremos com a abreviação ISIDORO, 1975. Na primeira, utilizamos a versão: ISIDORO DE SEVILHA, Chronicon. In: MIGNE (ed.). Patrologia Latina, t. 83, c. 1017-1058. Citaremos por ISIDORO, 1855(2), PL .

${ }^{12}$ Agostinho, na Cidade de Deus, desenvolve a sua filosofia da História. Demonstra como a marcha da humanidade, com todas as atribulações através do tempo, obedece a um plano divino. V. nota 6.

${ }^{13}$ A Patrologia não é referenciada através de páginas, mas sim de colunas (c), e de versículos (v). Tal qual numa referencia bíblica, não se usa páginas.
} 
ISIDORO, 1951, p. 112). Se lembrarmos que, na época de Sisebuto, Jerusalém fora tomada pelos persas de Cosroes, podemos supor alguma relação entre o fato e o texto. Isidoro também é o autor de uma cronologia semelhante, com seis idades do mundo, concluída no reinado de Sisebuto e que aparece no final do quinto livro das "Etimologias", com o mesmo comentário de que o tempo que restava da sexta idade era apenas do conhecimento de Deus (ISIDORO, 1951; 1982). A repetição dessa afirmação em duas obras de envergadura mostra a sua importância nas convicções de Isidoro. Essa concepção histórica reflete um sentido escatológico da História de forte influência agostiniana que permeia toda a obra isidoriana: o sentido e a razão de ser deste mundo estavam predeterminados por Deus e previstos nas Escrituras.

A outra obra histórica bastante conhecida, é a "Historia Gothorum" ou "História ou Histórias", também denominada "Isidori Historiae" ou "Origine Gothorum, Historia Wandalorum, Historia Sueborum" ${ }^{14}$ Escrita em 624 e reeditada e ampliada em 631, tornou-se um referencial para a história dos povos bárbaros na Hispania. ${ }^{15}$ Trata-se de três histórias diferentes e expostas em separado. A dos vândalos contém o período da presença desse povo na Hispania e também seu reino africano até sua destruição pelos bizantinos (ORLANDIS, 1988, p. 358). A história dos suevos se encerra com a anexação de seu reino por Leovigildo. ${ }^{16}$ Para a terceira parte, que trata dos visigodos, possivelmente o autor utilizou diversas fontes, tais como: Orósio, Hidácio de Chaves, Próspero de Aquitânia, Cipriano e, em especial, a obra do Biclarense (ORLANDIS, 1988, p. 356-357) escrita na segunda metade do século VI. Assim fundamentada, a História isidoriana se torna um marco importante para a historiografia ibérica. Não nos referiremos à parte que trata dos vândalos e dos suevos, mas apenas aos visigodos.

Resumindo a obra, podemos descrevê-la inicialmente por tópicos principais: inicia com o relato de remotas origens dos godos. Mostra a valentia desse povo, suas vitórias e seus feitos militares. Descreve a unificação da Península Ibérica, com a narrativa da obra de reis visigodos arianos, como Leovigildo, a sua unificação religiosa com Recaredo (III CT-589) e a definitiva "unidade política" com Suinthila, que expulsa definitivamente os bizantinos. ${ }^{17}$ Seu objetivo é amplo, mas quer exaltar o encontro da Hispania com os visigodos e fortalecer a monarquia católica. Alguns historiadores veem na obra um acentuado nacionalismo (TEILLET, 1984), o que nos parece anacrônico. A obra de Reydellet $(1961 ; 1981)$ amplia, tece críticas e contextualiza de maneira mais ampla essa visão.

Na parte inicial da "História" isidoriana, denominada "Laus Spaniae", o autor faz uma entusiasmada descrição das riquezas, da população e da paisagem da Espanha. Na visão de

\footnotetext{
${ }^{14}$ Obra que citaremos com a referência ISIDORO, 1975.

${ }^{15}$ Há fortes indícios de que Isidoro se utilizou de Victor Tunnunensis, para escrever a "Historia Wandalorum" e da

"Chronica" de Hidácio de Chaves, para escrever a "Historia Sueborum".

${ }^{16}$ Utiliza como fonte a "Crônica" de João de Bíclaro, que também é usada para descrever o reinado de Leovigildo.

${ }^{17}$ Unidade sempre contestada pelos vascones e por outros povos que se insurgiam no norte da Península Ibérica.
} 
Diaz y Diaz (2000, p. 110): nesse trecho, realiza uma mistura de realidade com ficção. Diz o autor: "[...] basada en métodos retóricos, adopta la forma de un panegírico en el que se funden lo genuino y lo artificioso". Descreve um encontro amoroso entre a Hispânia e os godos: possuída e amada pelos romanos, destes foi retirada, sendo "[...] conquistada e amada pela florescente nação dos godos" (ISIDORO, 1975, p. 171). A ligação entre os godos e a Hispânia é parte de uma justificativa histórico-literária do direito do conquistador. Alguns críticos têm restrições quanto à autenticidade desse texto, pois nada fala da Igreja nem dos triunfos cristãos na Hispania. Inclui certas construções historiográficas que se aproximam do mythos e aponta para uma duvidosa origem dos visigodos.

O que motiva Isidoro a buscar tais origens pouco fundamentadas? O que tenta provar? A sua motivação central, a nosso ver, é inserir os visigodos na história universal e obter para eles um lugar à altura de sua glória e de seus feitos: uma espécie de legitimidade histórica para o papel que Isidoro passa a atribuir aos visigodos, povo corajoso, lutador e de origens nobres. Isidoro usou de toda a sua erudição e de toda a sua habilidade literária para provar essas teses, considerando os godos, descendentes dos citas e do personagem bíblico Magog, filho de Jafet, filho de Noé (ISIDORO, 1975, p. 173).

$\mathrm{Na}$ análise da bibliografia e da "História" isidoriana, constatamos que essa construção historiográfica objetiva elaborar um passado glorioso para seu objeto. A descendência de Magog é uma interpretação derivada da afirmação de Ambrósio após a batalha de Adrianopla, associando o resultado da batalha a uma profecia de Ezequiel (c. 38-39). ${ }^{18}$ Também num trecho das "Etimologias", Isidoro reafirma a ligação entre visigodos e hispano-romanos numa ascendência bíblica comum, asseverando que os hispanos e os itálicos são originários de Tubal e os godos ou getas descendem de Magog (ISIDORO, 1951; 1982, L. IX, c. 2, v. 29 e 89).

Fica-nos a impressão de que realmente Isidoro acreditava nessa origem e nessa genealogia. Ao mesmo tempo, essa crença facilitou a Isidoro a busca de uma origem comum que justifique um relacionamento histórico ancestral dos visigodos com os hispanosromanos, no intuito de contribuir para a aproximação iniciada nos reinados de Leovigildo e seu filho e herdeiro Recaredo. Também permite a Isidoro realçar a antiguidade e a nobreza dos godos diante dos romanos e dos demais povos germânicos e qualificá-los para constituir um reino legítimo.

Eusébio já fizera isso ao realçar a antiguidade dos hebreus e, portanto, do texto bíblico; Flávio Josefo também faz isso em várias de suas obras, para mostrar a antiguidade de sua religião e a nobreza de suas origens. Isidoro tem excelentes referências para fazer sua reconstrução e elaborar origens nobres para os visigodos. Assim, eles entram na Bíblia, fazendo parte da herança judaico-cristã. Cazier (1994, p. 16) afirma: "Isto seria uma forma de

\footnotetext{
${ }^{18}$ A profecia não exalta os godos, mas Isidoro trata de fazer sua leitura e adequá-la a seus propósitos.
} 
lhes colocar na história do mundo, no enfoque da Bíblia". ${ }^{19} \mathrm{E}$ complementa que Isidoro aparenta-os com os gregos, italianos, leia-se romanos; e iberos, leia-se hispano-romanos. Outro aspecto seria a percepção da obra pela sua intenção ampla: ao mostrar as nobres origens dos godos e sua importância na História, seus feitos e sua postura cristã, trata de justificar a escolha desse povo como o substituto de Roma (FELDMAN, 2010). Isidoro constrói essa concepção sistematicamente. Isso se vê em mais trechos das obras isidorianas, mas não nos alongaremos.

Uma última obra isidoriana pode ser considerada como biográfica, ainda que se aproxime mais do gênero hagiográfico: a coletânea "De viris illustribus", sequência da obra de Jerônimo, continuada por Genádio, um sacerdote semipelagiano de Marselha (VALDEAVELLANO, 1988, p. 300). A obra contém biografias de personagens ilustres da Igreja, a maioria bispos (ORLANDIS, 1988, p. 17, 232, 355, 358).

Na versão isidoriana, são trinta e três biografias, dentre as quais, de doze personagens hispânicos, sendo seis de contemporâneos de Isidoro, incluído seu irmão, o bispo Leandro (DIAZ Y DIAZ, 2000, p. 111). A obra foi continuada por Ildefonso de Toledo.

A intenção clara é oferecer modelos de vida cristã e de virtudes. O modelo gregoriano que enfatiza um ideal monástico e pastoral é acentuado nas duas versões, isidoriana e ildefonsiana (FONTAINE, 1988, p. 95). Assim como nas hagiografias, o sentido pedagógico, tão acentuado em Isidoro que viveu numa época de confronto com arianos, de busca da consolidação da hegemonia da Igreja e da conversão dos pagãos, hereges e judeus, perpassa as razões de ser dessa obra. Biografias mostram caminhos, que podem ser modeladores e motivadores. Toda a obra de Isidoro objetiva delinear as veredas da Igreja e dos fiéis: é essencialmente cristã e educativa.

Nesta etapa, podemos tentar distinguir algumas intenções do autor no conjunto de sua obra histórico-literária. A maioria pode ser considerada como inserida numa concepção providencialista da História. Em todas há a presença da Providência divina, mas na "História" isso é mais evidente. Numa síntese inicial, podemos comparar as três obras históricas de Isidoro e refletir sobre elas.

A "Crônica" trata de relatar de maneira ampla a história universal, mostrando o surgimento do Cristianismo e a sexta era. Tece críticas ao paganismo ao longo da quinta e da sexta era e, ao mesmo tempo, condena a heresia. Já o "De Viris" enfoca personagens clericais, tratando de centrar a crítica às heresias: dezesseis personagens, entre os trinta e três referenciados por Isidoro, têm alguma relação com a heresia (HILLGARTH, 1985, p. 293). Por seu lado, a terceira obra, a(s) "Historia(s)" tem seu foco na glória dos visigodos e de seus reis. Se existe alguma oposição ou crítica esta é direcionada a Bizâncio. A obra é francamente

${ }^{19}$ Voilà pour le situer dans l'histoire du monde vue par la Bible. 
antirromana: a ousadia de condenar Justiniano, como herético, reflete um gesto de independência teológica e política (HILLGARTH, 1985, p. 297). Na Hispânia, desde o III Concílio de Toledo (CT), definiram-se como concílios definidores da fé e aceitáveis: Niceia sob Constantino, Constantinopla sob Teodósio I, Éfeso sob Teodósio II e Calcedônia sob Marciano. Pode-se ver o texto desses sínodos, na abertura do texto do III CT (VIVES, 1963). O concílio de Justiniano é considerado herético e esquecido de todas as referências. $\mathrm{Na}$ sequência, faremos a junção da "História" com outras obras, para tentar entender a visão isidoriana da política e da sociedade.

\section{A obra histórica e a concepção política Isidoriana}

Isidoro de Sevilha mantém uma unidade de pensamento em toda a sua obra. Fica-nos a impressão de que toda a sua obra tenta oferecer uma ampla reflexão sobre o saber clássico e eclesiástico, objetivando sempre a elevação de espírito de clérigos e letrados da Hispania. $\mathrm{O}$ projeto global de sociedade foi resumido por Fontaine como sendo definido em quatro tópicos principais: "Reino godo, rei justo, cidade de Deus peregrina e romanidade" (FONTAINE, 1990, p. 272). ${ }^{20}$ Sua concepção de Monarquia se insere nesse projeto global e dentro dele deve ser compreendida. Em sua obra, procura construir um modelo de rei cristão ideal e de uma Monarquia que cumpra o seu papel na História, ajudando a aproximar a segunda vinda de Cristo.

Com Isidoro, a concepção do monarca cristão, desenvolvida a partir de Constantino, transforma-se. Os monarcas do Baixo Império eram concebidos como defensores da fé e da Igreja católica: sua proteção e seu respeito pela fé cristã são o pilar da relação entre Imperium e Ecclesia. Reydellet (1981, p. 554-555) entende que Isidoro inova, ao conceber a realeza não mais como o produto do direito natural, mas como o governo do povo cristão. $O$ autor afirma que a novidade de Isidoro é que ele concebe: "[...] a realeza, não mais como o produto da lei natural, mas como o governo do povo cristão como tal". ${ }^{21} \mathrm{E}$, fundamentado na reflexão de Gregório Magno e Agostinho, enfatiza a noção de função e serviço. Diz: "O foco é colocado, portanto sobre o conceito de função e serviço [...]” (REYDELLET, 1981, p. 554555). ${ }^{22} \mathrm{O}$ momento histórico favorece a construção de um modelo renovado de monarca: Isidoro compreende essa situação e almeja definir uma nova concepção de monarca cristão. O momento que sucede ao III CT e à conversão de Recaredo propicia a aparição de novas condições. Em 589, já ocorrera a conversão do rei e da nobreza visigodos ao catolicismo e finalmente se unificará a maior parte do território com Suintila: o objetivo da unidade do

\footnotetext{
${ }^{20}$ Patria Gothorum, rex rectus, civitas Dei peregrinans, et romanitas. A tradução do conceito de Patria Gothorum corre sério risco de gerar um anacronismo, por isso optamos por traduzi-la como reino godo. Nada que possa lembrar nação no sentido contemporâneo. O conjunto exprime a visão cristã de mundo, a influência cultural romana, a monarquia cristã e o contexto político visigodo.

${ }^{21}$ [...] la royauté non plus comme le produit du droit naturel mais comme le gouvernement du peuple chrétien en tant que tel.

${ }^{22}$ L'accent est mis ainsi sur la notion de fonction et de service [...].
} 
reino visigodo está sendo atingido (REYDELLET, 1961, p. 457). Os reinados de Liuva, Viterico e Gundemaro foram uma fase de transição. A ascensão ao trono de Sisebuto renova em Isidoro a expectativa de diálogo com o monarca.

Nas obras de Isidoro, podemos encontrar reflexões sobre a Monarquia que propiciam análise e reflexão mais profunda sobre a visão do hispalense relativa à função do monarca cristão. Em três dessas obras, percebemos reflexões importantes para entender a construção da concepção isidoriana de Monarquia. Reydellet (1961, p. 457) concorda conosco, quando delineia as fontes sobre a concepção do soberano cristão em Isidoro, citando as "Etimologias", as "Sentenças" livro III, e alguns trechos da "História". Consideramos que podemos dizer que, de certa maneira, toda a obra de Isidoro reflete a busca de um por que da História, no duplo sentido da universalidade da Divina Providência e do direito público da tradição romana. O autor espanhol Garcia Moreno (1989, p. 111) concebe que os pensadores hispano-visigodos estavam preocupados em encontrar "[...] un sentido a la historia contemporánea en el doble plano de la universalidad de la Divina providencia y del derecho público de la tradición romana...bajo el ropaje ideológico del dominio [...] de la gens Gothorum, de la nación goda".

Isidoro insere a tradição política e jurídica romana na concepção cristã de mundo. Esta visão pode ser percebida na visão da monarquia, de acordo com Isidoro, que não é historiador, e seu recorte temático visa a transmitir uma mensagem: todo gesto, todo exemplo e toda a atitude tomada pelos personagens têm alguma razão para terem sido selecionados e descritos na obra. É uma seleção minuciosa de exemplos do que um monarca deve ou não deve fazer. Assim sendo, um dos eixos temáticos é modelar atitudes corretas de reis cristãos e contrapor, como modelo negativo, as posturas inadequadas e as punições que recaem sobre os que se desviam do bem e da verdade cristãs.

Na sua "História", obra repleta de detalhes interessantes, pode-se perceber um recorte ideológico da presença dos visigodos na história do mundo tardo antigo. $O$ trecho de abertura da obra pode parecer alheio às questões religiosas e políticas, assemelhando-se a um mito, mas é a construção sutil de uma legitimidade à Monarquia e de um suporte às pretensões clericais, que apoia o poder real e dele depende para se fortalecer e expandir.

O trecho inicial "De laude Spaniae", já descrito por nós, faz alegoricamente um elogio e exaltação da Espanha, quando constrói uma identidade territorial do espaço ibérico. Dentro da visão isidoriana, a Hispania seria uma formosa mãe, fecunda e bela, produtiva e por todos desejada (ISIDORO, 1975, p. 168-170). Tomada pelos romanos, mas destes viúva, é desposada pelos visigodos. Um simbólico e romântico encontro? É uma alegoria que descreve o encontro do povo, da terra e da unidade político-religiosa almejada pelo autor. Desse modo, Isidoro traça as raízes deste encontro singular: a Espanha, que espera por seu amado, e o povo godo. 
Teillet (1984, p. 498) ressalta que, no prólogo da obra, Isidoro traça o encontro da gloriosa gens Gothorum com a Espanha, descrita como uma mãe fecunda. Tendo desposado antes os romanos, agora desposa a gens Gothorum, alegoriza uma semelhança nada casual com a cidade de Jerusalém, viúva e abandonada que encontra um novo e vigoroso esposo: o seu Salvador e Redentor. A redenção se avizinha e o espaço é esse; a ausência do Império não gera problemas, pois surge um novo protagonista para ser associado.

A construção não é traçada de maneira simples e aleatória: Isidoro busca no longínquo passado, as glórias e as nobres origens da Gens gothorum. Encontra, em Magog, filho de Jafet, o ancestral bíblico para o povo eleito (ISIDORO, 1975, p. 172-173) ${ }^{23}$ A construção segue por tortuosos caminhos, geralmente sem fundamento em crônicas nem em autores clássicos: os godos aparecem na guerra civil entre César e Pompeu, no final da República romana, mas do lado do último, fortalecendo a legalidade e a Respublica. Descreve sua participação na luta armada, quando "[...] os godos chegaram a Tessália para prestar ajuda a Pompeu e lutar contra César" (ISIDORO, 1975, p. 174-175). Isidoro não qualifica suas fontes, e nenhuma citação confirma essa participação.

Em outro trecho, os godos conflitam com os imperadores do Baixo Império, entre os quais se encontra Constantino (ISIDORO, 1975, p. 178-179). As vitórias de renomados chefes militares romanos sobre os godos são mencionadas para acentuar que somente grandes generais conseguiram vencê-los: César e Constantino. Teillet (1984, p. 482) diz que a presença de godos na batalha de Farsália, entre César e Pompeu, é um anacronismo, que pode ser uma invenção de Isidoro.

Constrói sua obra em busca de seus objetivos: exaltar a nobreza do noivo godo diante de sua noiva Espanha. No caso de Constantino versus godos, ele realça duas tradições: os corajosos godos e os renomados comandantes militares romanos. Enfatiza a glória pública dos citados generais romanos, por terem vencido os imbatíveis godos. Usa da derrota para exaltar seus heróis (CAZIER, 1994, p. 17). Constantino foi o protetor da Igreja, e os godos ora se tornavam como tais.

Nem a batalha de Adrianopla que descrevemos quando falamos de Jerônimo, é considerada, não como um desastre romano (ótica romano-centrista), mas sim uma justificada reação dos godos à violência dos imperiais e uma vitória dos bons e justos: a descrição da morte do imperador Valente ferido por uma flecha, sendo, em seguida, queimado é um exemplo disso (ISIDORO, 1975, p. 186-187). Na verdade, trata-se de uma nova alegoria isidoriana. Isidoro faz uma interpretação alegórica da maldade de Valente: em sua "versão histórica", os primeiros godos que se converteram ao Cristianismo se tornaram católicos, mas Valente enviara um missionário ariano (Ulfilas ou Gulfilas), que viria a

\footnotetext{
${ }^{23}$ Essa genealogia é traçada apenas com o fundamento de evidenciar a semelhança entre as três últimas letras de Magog com godos, e uma referência bíblica de Ambrósio, após a batalha de Adrianopla, vitória goda contra Roma. Uma prova nada convincente, mas uma argumentação que dá um efeito de nobreza e estirpe aos godos.
} 
convertê-los; esses godos arianos teriam ardido no "fogo eterno" por sua opção ariana. A culpa disso seria de Valente, que teria sido punido da mesma maneira, ardendo em chamas (ISIDORO, 1975, p. 186-187). Teillet (1984, p. 483) diz que esse clichê foi passado por Orósio a Jordanes e a Isidoro. Afirma: "[...] esta imagem (clichê) também foi tirada de Orosius por Jordanes". ${ }^{24}$

Essa leitura alegórica se repete em toda a obra: uma construção de situações e análises, em que causa e efeito, pecado e punição se sucedem. A postura e o valor dos godos são usualmente louvados: Isidoro exalta sua coragem, seu senso de liberdade e sua aptidão para governar. As suas razões são ideológicas e muito visíveis. Fontaine (1986, p. 117) afirma: "A trama ideológica do livro é clara: grandes temas góticos (valentia dos godos, seu senso de liberdade, a sua capacidade de governar)". ${ }^{25}$ Para isso atenua os erros ou a violência goda.

Um exemplo é a descrição da entrada dos godos em Roma com Alarico: os godos protegem e não invadem os lugares sagrados, isto é, as igrejas católicas. Não ferem, nem matam, nem escravizam os que se refugiaram nas igrejas e tampouco os que clamaram em nome de Cristo e dos santos. O Hispalense afirma que não tocaram os que se refugiaram nos lugares santos: "[...] et mors et captivitas indultas est qui ad sanctorum limina confugerunt". E também pouparam os que pronunciaram o nome de Cristo e dos santos, mesmo se fora dos locais sagrados: "[...] et nomen Christi et sanctorum nominaverunt". Isidoro delineia uma revisão histórica dos godos como um povo repleto de nobreza e pietas, portadores da civitas (ISIDORO, 1975, p. 194-195).

Há duas percepções distintas dos reis visigodos: os arianos, ou seja, heréticos são analisados de uma maneira negativa e tendo seu destino acoplado à sua opção religiosa. Os reis godos arianos são descritos, quase ininterruptamente como tendo sido assassinados por algum dos seus seguidores: Alarico e Ataulfo não deixam sucessores, e isso é associado à profecia de Daniel (ISIDORO, 1975, c. 18); Sigerico é morto pelos seus seguidores (c. 20); Turismundo é assassinado por seus irmãos (c. 30); Teuderico é assassinado por seu irmão Eurico (c. 33); alguns reis morrem de morte natural, como Vália e Eurico.

Qual é a importância dessas descrições? Em quase todas há uma moral implícita: morrem ou são punidos pelo que fazem. A presença de Deus e dos demônios é constante na História e se encontra também na história dos visigodos, durante o período visigodo-ariano, que antecede a conversão de Recaredo.

Um exemplo é a descrição da batalha entre Átila, rei dos hunos, e uma coalizão romanogermânica: a descrição de prodígios no céu e na terra (terremotos, eclipses, cometa, coloração vermelha como sangue na parte norte do céu), tudo isso Isidoro interpreta como

\footnotetext{
24 “[...] ce cliché était également emprunté à Orose par Jordanès".

25 "[...] La trame idéologique du livre est claire: des grands thèmes gothiques (la vaillance des Goths, leur sens de la liberté, leur aptitude à gouverner)" .
} 
sendo obra divina para simbolizar a carnificina da batalha (ISIDORO, 1975, p. 214-215). Afirma que o desastre e a derrota dos hunos foram castigos celestes (caelestibus plagis), uma clara intervenção de Deus, na História, nas batalhas e nas ações humanas. Na concepção isidoriana da História, a presença e a intervenção divina estão delineadas nos eventos.

A obra de Isidoro (História) difere da obra do Biclarense, que tem o Império como centro e referência cronológica: o reino visigodo é o foco central e só a história do encontro da Hispania e dos visigodos é que interessa. Não se pode dizer que há um rompimento com a cultura clássica. Isidoro afirma implicitamente que a cultura e a civilização romanas foram assumidas e continuadas por um povo germânico, romanizado e portador de uma nobreza sem igual (REYDELLET, 1961, p. 463-464). Ele não acredita em uma ruptura, com as invasões. Entendendo o Império como um "meio cultural", compreende que havia uma continuidade. O uso da expressão provincia na laus Spaniae reflete essa visão (ISIDORO, 1975, p. 168-169). Descreve a Hispania como a "reginae provinciarum", ou seja, a rainha de todas as províncias. Uma mistura de pertinência e de separação: continuidade e diversidade.

\section{A biografia Real}

A "História" é um livro claramente ideológico que retrata as pessoas e os fatos de acordo com a visão isidoriana de mundo. Autores como Fontaine e Reydellet reforçam essa opinião. Uma das questões levantadas por ambos é a da biografia real. Reydellet entende que a galeria de reis, apresentada de maneira simbólica, é retratada em um julgamento no qual o bem é recompensado e o mal punido.

A partir dos últimos reis arianos e dos reis católicos com os quais Isidoro conviveu, os fatos são acompanhados pelo retrato moral dos príncipes (REYDELLET, 1981, p. 526). Podemos deduzir que se trata de uma clara associação dos príncipes católicos nicenos com o bem, retratada por meio de recursos aparentemente literários e historiográficos, uma ideologia que por vezes tende a um dualismo. Na opinião do autor, Isidoro faz uma obra claramente permeada de uma ideologia. A sua visão de mundo e do papel dos reis está em cada trecho. Diz: "[...] que à estética literária se adicionou conscientemente ou não uma ideologia" (REYDELLET, 1981, p. 523). ${ }^{26}$

A biografia real não era uma novidade na época de Isidoro: Sidônio Apolinário escrevera sobre Teodorico II; Cassiodoro sobre Teodorico o Grande; e Gregório de Tours sobre Clóvis e a dinastia merovíngia. O interesse variava, mas sempre se oferecia um modelo e um exemplo. A maldade de certos reis se associava à sua morte de maneira cruel. A função da biografia é basicamente centrada em dois aspectos: a) colocar os reis diante de suas responsabilidades e mostrar que eles não são um joguete da história, sofrendo as

\footnotetext{
${ }^{26}[. .$.$] que l'esthétique littéraire rejoint, conscienment ou non, une idéologie.$
} 
consequências de suas atitudes e ações; b) servir de exemplo para seus sucessores e para os povos, sendo um modelo político e social.

Neste caso, Isidoro faz claramente um juízo de valor, direto ou simbólico, explícito ou implícito. Em todos os reis que retrata, usa a mesma estrutura narrativa adotada no De ortu, obra de exegese, na qual faz minibiografias de personagens bíblicos: como nasceu, o que fez e como morreu (ISIDORO, 1985). Isidoro insere a exegese como modelo de escrita da História. Faz das biografias modelos de vida cristã e de governantes cristãos em específico.

O rei Leovigildo, o primeiro contemporâneo de Isidoro, é descrito com louvor pelo seu papel de unificador e vencedor de batalhas, mas foi duramente criticado por sua política religiosa. Isidoro dedica um capítulo a exaltar suas ações militares (ISIDORO, 1975, c. 49) e contrapõe outro capítulo a criticar sua ação religiosa (c. 50); num terceiro capítulo (c. 51), fala da obra unificadora do rei em termos internos, criticando seus excessos e sede de poder. Ataca sua política religiosa, mas elogia seus feitos político-militares. Na visão de Reydellet (1981, p. 530), Isidoro descreve a grandeza de Leovigildo mesmo sendo ferozmente crítico à sua obra religiosa.

Refere-se à atitude de Leovigildo de tentar atrair católicos ao arianismo, que, segundo Isidoro, pouco resultou; obteve algumas conversões pela violência, mas só deu certo nos casos em que ocorreu suborno (corrupção). No dizer de Isidoro: "[...] plerosque sine persecutione inlectos auro rebusque decepit"(ISIDORO, 1975, c. 50). Uma utilização do poder de maneira tirânica, na ótica isidoriana.

Apesar disso, deixa transparecer que Leovigildo é um modelo monárquico: funda cidades, cunha moedas, desenvolve um ritual de corte e majestade (ISIDORO, 1975, c. 51) e se torna de fato o fundador da Monarquia toledana, e um exemplo modelar na obra isidoriana. $\mathrm{Na}$ opinião de Reydellet, Isidoro trata Leovigildo como um símbolo, um modelo monárquico: "É correto dizer que aos olhos do sevilhano, Leovigildo se transforma num símbolo: ele é realmente o fundador da monarquia toledana” (REYDELLET, 1961, p. 464). ${ }^{27}$

Isidoro se omite de dizer algo sobre o concílio ariano e a tentativa de unificar os cristãos da península ibérica, numa Igreja nacional de orientação ariana, e é extremamente conciso ao comentar a revolta de Hermenegildo, um claro caso de revolta "tirânica", ou seja, ilegal e contra a estabilidade do governo legítimo. Isidoro concorda com o Biclarense e sua versão quase "telegráfica". Afirma-nos Fontaine (1986, p. 118), deixando explícito o incomodo, e enfatiza que a menção de Isidoro: "[...] É rápida e sem amenidades". ${ }^{28}$ Certo incômodo de tratar desse tema pode ser percebido. Um silêncio comprometedor que denuncia uma sensível questão.

\footnotetext{
${ }^{27}$ Il est certain qu'aux yeux du Sévillan, Liuvigild fait figure de symbole: il est vraiment le fondateur de la royauté tolédane

${ }^{28}$ [...]est rapide et sans aménité.
} 
O mesmo cuidado tem ao tratar de seu irmão, o bispo Leandro de Sevilha, que teve papel fundamental na revolta de Hermenegildo e se aliou com o inimigo bizantino num colaboracionismo que pode ser entendido como traição à Hispania e à gens Gothorum.

Fontaine (1986, p. 117-118) afirma: “[...] Não há nada sobre a colaboração de Leandro com os bizantinos, sobre a sua traição ao príncipe reinante, seu provável papel na rebelião de Hermenegildo [...]". ${ }^{29}$ Outro silêncio que fala alto: uma traição ao poder legítimo e uma aliança com um dos maiores inimigos do Estado. Há silêncios que falam mais que mil palavras.

O personagem-modelo que segue a Leovigildo é seu filho e sucessor Recaredo. As aclamações registradas nas atas do III CT (589) deixam uma ideia do prestígio de Recaredo junto ao clero hispânico. Isidoro descreve o príncipe como modelo para seus sucessores. $\mathrm{O}$ propósito de grande parte de sua obra, e especificamente do livro "História", é propiciar um modelo, "[...] seja na forma teórica, como um tratado de Ética, seja na forma de um relato da vida e das virtudes dos reis que conseguiram, ou estiveram muito perto de conseguir, a perfeição almejada" (MARTIN, 1996, p. 87). Os personagens isidorianos modelares realizam, pelo menos parcialmente, esse ideal de príncipe cristão, entenda-se católico (REYDELLET, 1981, p. 463).

Os dois monarcas mais exemplares são Recaredo e Suintila, já que cada qual, a seu modo, dá continuidade ao processo de unificação religioso e territorial. Isidoro mostra nos dois, qualidades ímpares e constrói seu modelo de monarca.

Reydellet (1981, p. 463, grifo do autor) diz que o gênero histórico permite a Isidoro: "[...] sugerir um ideal da monarquia visigótica e destacar alguns aspectos puramente políticos que não têm um lugar no quadro moralizante das Sentenças". ${ }^{30} \mathrm{Ou}$ seja, tudo o que não se insere numa obra teológica e moralista, como as "Sentenças", pode servir de complemento à construção de um modelo de monarca, num livro histórico que cumpre, assim, sua função de ensinar através do tempo histórico, os caminhos de Deus. Eis aqui o sentido da escrita da "História" para Isidoro.

Recaredo é objeto de um panegírico, ao estilo dos panegíricos dos imperadores, mas lembrando, em alguns aspectos, o que virão a ser, os "espelhos de príncipes medievais". Os melhores dons físicos e espirituais lhe são atribuídos: respeito pela religião, piedoso e pacífico (c. 52). Isidoro diz assim: religioso (cultu praeditus religionis), piedoso e pacífico (hic fide pius et pace praeclarus). Essas qualidades aparecem em contraste com as de seu pai, Leovigildo, denominado irreligioso (inreligiosus), inclinado para a guerra (et bello

\footnotetext{
${ }^{29}$ [...] rien sur la 'collaboration' de Léandre avec les Byzantins, sur sa trahison du prince régnant, sur son rôle probable dans la rébellion d' Hermenegild[...].

${ }^{30}$ [...] de suggérer un idéal de la monarchie wisigothique et de souligner certains aspects proprement politiques qui n'avaient pas leur place dans le cadre moralisant des sententiae.
} 
promptissimus) (ISIDORO, 1975, p. 260-261). O contraste não é casual e espelha uma diferenciação entre um príncipe cristianíssimo e um príncipe ariano.

Administrou as províncias com equidade e moderação. Era tal a sua bondade, que até seu rosto refletia tal benevolência e chegava a atrair o carinho e o afeto dos maus; agiu de maneira liberal com os que sofreram confiscos de seu pai, restituindo-lhes seus bens, tanto para os senhores como para a Igreja (ISIDORO, 1975, p. 264-267). Essa liberalidade pode ser interpretada como qualidade ou defeito: enfraquecer a Monarquia, devolvendo terras ao clero e à nobreza, como parte de acordos políticos.

Isidoro alegoriza os seus personagens e os associa a modelos bíblicos. Em suas obras de exegese, criou modelos e pares. Isso pode ser percebido, por exemplo, nas "Alegorias" e no "De Ortu", onde são comparados pais e filhos, personagens de certos períodos e são criados modelos, seja de protagonistas bons, seja de personagens malignos.

As semelhanças entre os personagens da "História" com as do "Ortu" não são casuais: há certos paralelismos na visão isidoriana, entre Leovigildo e Recaredo, com outro conjunto de pai e filho: Davi e Salomão. Um guerreiro e o outro pacífico; o filho muito mais sábio que o pai. Além disso, exalta o monarca godo, acima do hebreu.

Isidoro diferencia o final dos dias de Salomão, inadequados e em desacordo com sua trajetória de vida, e os últimos dias de Recaredo, um monarca coerente e modelar desde o início de seu reino até sua morte. Estabelece assim inequívoca diferença entre Recaredo e Salomão. Este último se distancia de seus valores na hora da morte. Recaredo, por seu turno, afasta-se também de seu similar imperial, Constantino, que, de forma incoerente, foi algumas vezes partidário do arianismo e manteve seus laços com o paganismo (ISIDORO, 1975, c. 52).

Reydellet (1981, p. 540) enfatiza que, de acordo com Isidoro, Recaredo foi coerente em suas ações: "Recaredo pelo contrário, seguiu ao longo de todo o seu reinado o caminho correto". ${ }^{31}$ Há uma razão importante a ser explicada. O final de cada personagem no "De Ortu" tem um significado ético, serve como ensinamento. O mesmo se dá com Recaredo. Vale lembrar que Constantino nunca renunciou totalmente às suas crenças pagãs. Isidoro insiste que Recaredo já havia se convertido desde o início de seu reinado (ISIDORO, 1975, p. 260-261). Isso destoa das informações do Biclarense: Recaredo se converteu no décimo mês do primeiro ano de seu reinado (JOÃO DE BICLARO, 1960, p. 30, 138).

Isidoro descreve uma vida coerente, tal como os modelos bíblicos do "De Ortu", em que a hora da morte é um momento crucial: o arrependimento e a busca de Deus, mesmo que tardia, pode ser a salvação. A morte de Recaredo é descrita como a conclusão de sua missão coroada: "[...] sabendo que o reino que lhe havia sido encomendado por Deus para utilizar

\footnotetext{
${ }^{31}$ Reccaréde, au contraire, a suivi tout a long de son règne la voie droite.
} 
dele no objetivo da salvação, tanto de si próprio quanto de seus súditos, tratou de alcançar com bons princípios um bom fim [...]"; e prossegue dizendo: "[...] e desta maneira a fé da verdadeira glória que recebeu no início do seu reinado, tratou de acrescentar, há pouco tempo, com a profissão pública de arrependimento" (ISIDORO, 1975, p. 266-267). O sentido pedagógico e cristão da sua escrita da "História" é desvendado aqui.

No entender de Reydellet, isso corresponde à visão isidoriana dos últimos tempos que, no microcosmo, espelha o macrocosmo da escatologia: os últimos momentos da vida são fundamentais para um grande homem se unir a Deus e à sua obra. Afirma, em sentido menos amplo que o utilizado por nós, a importância dos últimos gestos de um personagem: "De uma maneira geral, a escatologia de Isidoro enfatiza os últimos momentos da vida. Várias vezes ele repete que conta apenas o último ato, o que é especialmente reconfortante para os arrependidos de última hora" (REYDELLET, 1981, p. 540). ${ }^{32}$

Assim, toda a coerência de uma vida foi dedicada à fé, à moderação, à justiça e à missão apostólica de converter e salvar seu povo, desde o início de seu reinado até sua morte: daí a necessidade de adiantar a sua conversão e contradizer o Biclarense, sua fonte principal. Na narrativa histórica isidoriana, há uma clara inserção da exegese e de modelos assemelhados aos personagens bíblicos, no dimensionamento e na construção dos personagens históricos.

Recaredo é declarado gloriosíssimo e religiosíssimo príncipe, no trecho da "Historia" que antecede a descrição geral do III CT; Isidoro fala a seguir de seu papel no processo de unificação e repete todo o dogma trinitário, como se pretendesse deixar clara, sua aceitação plena pelo rei e por todos os membros do concílio (ISIDORO, 1975, p. 262-263).

Os paralelos entre Leovigildo e Recaredo são evidentes. Contrapõem as virtudes do filho diante dos excessos do pai. Utiliza muitos verbos para definir Leovigildo e muitos adjetivos para compor a personalidade refinada e sacra do rei "apostólico". A personalidade de Recaredo é descrita em duas partes, uma sobre suas ações religiosas e político-militares e a outra para descrever sua personalidade e características pessoais. $O$ filho supera o pai e complementa sua obra em coerência com sua função de monarca cristão.

\section{Considerações Finais}

A obra isidoriana é um projeto educacional de uma sociedade. Pretende propiciar a manutenção de um clero mais bem organizado, expandir a evangelização e preparar o terreno para a segunda vinda do Redentor. Nas obras de exegese, nas "Sentenças" pode-se perceber o projeto de aprimoramento dos quadros clericais. Já nas obras históricas de Isidoro, há algumas tendências visíveis e perceptíveis. No nível amplo é possível mostrar o

${ }^{32}$ D'une façon générale, l'eschatologie d'Isidore insiste sur les derniers moments de la vie. Plusieurs fois, il répète que seul compte le dernier acte, ce qui est surtout consolant pour les ouvriers de la onzième heure. 
sentido cristão da História e demonstrar o Providencialismo e a Teleologia se inserindo na concepção agostiniana de História, mesmo sem o porte de um Orósio. No nível específico, gerar exemplos morais de governantes cristãos e criticar posturas inadequadas e malignas. Terá forte influência na escrita da história, no período denominado de "reconquista", por servir para legitimar a presença cristã no espaço peninsular.

\section{Referências}

BROWN, Peter. Santo Agostinho: uma biografia. Rio de Janeiro: Record, 2008.

CAZIER, Pierre. Isidore de Séville et la naissance de l'Espagne catholique. Paris: Beauchesne, 1994.

CHADWICK, Henry. Augustine of Hippo: a life. Oxford: Oxford University Press, 1986.

DIAZ y DIAZ, Manuel. Escritores de la Península Ibérica. In: Patrologia IV: del Concilio de Calcedonia (451) a Beda: los padres latinos. Madrid: BAC, 2000.

FELDMAN, Sergio. Origens nobres dos visigodos. In: LUPI, João. Druidas, cavaleiros e deusas: estudos medievais. Florianópolis: Insular, 2010. p. 273-286.

FONTAINE, Jean. Conversion et culture chez les wisigoths d'Espagne. In: . Culture et spiritualité en Espagne du IVe au VIIe siécle. Londres: Variorum Reprints, 1986. p. 88-147.

El De Viris illustribus de San Ildefonso de Toledo: tradición y originalidad. In: _ _ _ _ _. Culture et spiritualité en Espagne du IV au VII siècle. Londres: Variorum Reprints, 1988. p. 168-223.

. Isidoro de Sevilla, padre de la cultura européia. In: . La conversión de Roma: cristianismo y paganismo. Madrid: Ediciones Clásicas, 1990. p. 259-286.

GARCIA MORENO, Luis. Historia de España visigoda. Madrid: Cátedra, 1989.

HARTOG, François (Org.). A história de Homero a Santo Agostinho. Belo Horizonte: UFMG, 2001.

HILLGARTH, J. Historiography in Visigothic Spain. In: _____. Visigothic Spain, Byzantium and the Irish. London: Variorum Reprints, 1985. p. 80-169.

ISIDORO DE SEVILHA. Allegoriae quaedam sacrae scripturae. In: MOLINERO, L. La alegorias de la Sagrada Escritura de S. Isidoro de Sevilla. Buenos Aires: Cursos de Cultura Catolica, 1936. 
ISIDORO DE SEVILHA. Chronicon. In: MIGNE (Ed.). Patrologia latina. t. 83, c. 1017-1058. Paris: c. $1855(2)$

ISIDORO DE SEVILHA. De ortu et obitum patrum: vida y muerte de los santos: introducción. Paris: Societé d'Editions “Les Belles Lettres”, 1985.

ISIDORO DE SEVILHA. Etimologias. Madrid: Biblioteca de Autores Cristianos, 1951.

ISIDORO DE SEVILHA. Etimologias. Madrid: Biblioteca de Autores Cristianos, 1982.

ISIDORO DE SEVILHA. Las historias de los godos, vandalos y suevos (De origine gothorum, historia wandalorum, historia sueborum). León: Centro de Estudios S. Isidoro, 1975.

ISIDORO DE SEVILHA. Los tres libros de las "Sentencias ("Sententiarum" libri tres). Madrid: BAC, 1971 (Santos padres españoles II: San Leandro, San Isidoro, San Fructuoso).

ISIDORO DE SEVILHA. De viris illustribus, In: MIGNE (Ed.). Patrologia latina, t. 44. Paris: c. $1855(1)$

JOÃO DE BICLARO. Crônica. Madrid: C S I C, 1960.

MARKUS, Robert Austin. Saeculum: history and society in the theology of Augustine. Cambridge: Cambridge University Press, 1970.

MARTIN, Maria Guerra. A teoria política visigoda. In: DE BONI, Luís Alberto (Org.). Idade Média: ética e política. 2. ed. Porto Alegre: Edipucrs, 1996. p. 79-89.

ORLANDIS, José. Historia del reino visigodo español. Madrid: Rialp, 1988.

QUEIROZ, Tereza Aline; IOKOI, Zilda Marcia. A história do historiador. 2. ed. São Paulo: Humanitas, 2003.

REYDELLET, Marc. La conception du souverain chez Isidore In: Isidoriana. Leon: Centro de Estudios San Isidoro, 1961.

. La royauté dans la littérature latine de Sidone Apollinaire à Isidore de Seville. Roma: École Française de Rome, 1981.

SILVA, Marcelo Candido. A realeza cristã na alta idade média. São Paulo: Alameda, 2008.

TEILLET, Suzanne. Des goths à la nation gothique: les origines de l'idée de nation en Occidente du Ve au VIIe siècle. Paris: Belles Lettres, 1984.

TÉTART, Philipe. Pequena história dos historiadores. Bauru: Edusc, 2000. 


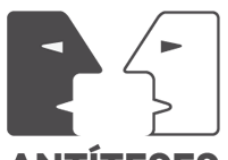

ANTÍTESES

VALDEAVELLANO, Luis García. Historia de España antigua y medieval. Madrid: Alianza, 1988.

VIVES, Jose Vicens (Ed.). Concilios visigóticos e hispanos-romanos. Madrid: Barcelona, CSIC, 1963.

WOLF, Kenneth Baxter (Org.). Conquerors and chroniclers of early medieval Spain. 2. ed. Liverpool: Liverpool University Press, 1999. 